\title{
The EU Queries: A Form of Extra-Judicial Preliminary Reference in the Field of Maladministration?
}

\author{
Natassa Athanasiadou ${ }^{1, *}$ and Nikos Vogiatzis ${ }^{2, * *}$ \\ ${ }^{1}$ Maastricht Centre of European Law, Maastricht University, Maastricht, Netherlands and ${ }^{2}$ School of Law, University of Essex, \\ Colchester, United Kingdom \\ Corresponding author: Nikos Vogiatzis, Email: n.vogiatzis@essex.ac.uk
}

(Received 31 March 2021; accepted 11 April 2021)

\begin{abstract}
This Article represents the first comprehensive study of the EU query process, a form of flexible extra-judicial cooperation between the European Ombudsman and the national ombud offices on the interpretation and application of EU law across member states. The way this cooperation is constructed brings imminently to mind the preliminary reference procedure: A national office submits a query within the scope of EU law to the European Ombudsman who, after consultation with the Commission-in the vast majority of cases-provides a reply. Upon closer examination, however, this Article illustrates key differences between the two procedures, while pointing out the added value of the EU query procedure compared to the preliminary reference. More specifically, while the interpretation that is provided is not authoritative or legally binding (among other differences), thanks to the flexibility of this instrument, interpretative guidance is provided at an early stage in case a problem in the interpretation and application of EU law arises, and thus litigation may be avoided. Furthermore, the EU query procedure serves as a reliable source of information for both the European and the national sides. However, this Article also identifies a number of challenges in relation to the transparency of the scheme, its effective functioning, as well as its interplay with other instruments, such as the infringement procedure.
\end{abstract}

Keywords: EU queries; preliminary reference; maladministration; extra-judicial redress; European Commission

\section{A. Introduction}

The means of extra-judicial cooperation between EU and national bodies in the field of maladministration, and the challenges arising thereof, remains an underexplored area of study. This cooperation aims to address, among other issues, instances of maladministration at the domestic level, especially when national authorities implement EU law. This Article sheds light on a significant form of extra-judicial cooperation in the European Union (EU): The EU queries procedure. This is the process whereby a national ombud office can send a "query" on EU law to the European Ombudsman, who then, usually after transferring the case to the Commission, provides

\footnotetext{
${ }^{*}$ Natassa Athanasiadou is Member of Cabinet of Commissioner for Budget and Administration, European Commission and member of the Maastricht Centre of European Law, Maastricht University. She is writing in a private capacity without representing the official position of the European Commission.

${ }^{* *}$ Nikos Vogiatzis is Senior Lecturer in the School of Law, University of Essex. 
a reply. The way this scheme operates, therefore, presents certain similarities with the preliminary reference procedure, the main form of cooperation between the Court of Justice of the European Union (CJEU) and national courts. A comparative examination of the two procedures is therefore warranted, not least because this will illustrate some of the key advantages, and simultaneously less-known features, of the EU queries process. It will be shown that, thanks to its speed and flexibility, the scheme plays a crucial role in the coherent and effective application of EU law, thereby complementing the preliminary reference procedure. This contribution also identifies and evaluates the challenges arising from the overall informal operation of the EU queries. These pertain, inter alia, to its limited transparency and visibility, the insufficient guidance from the EU office towards the national offices as to what should be included in the request, and, in cases where an infringement of EU law is unraveled, the limitations of the scheme to provide meaningful solutions in light of the Commission's broad discretion. Against these challenges, this Article will argue that the effectiveness of the EU query procedure will benefit from clearly delineating its features, outcome, and added value vis-à-vis other instruments.

Unlike the EU query process, the forms of cooperation between the CJEU and national courts and, in particular, the preliminary reference procedure under Article 267 TFEU, is a subject that has received extensive scholarly attention. ${ }^{1}$ As is known, in accordance with that provision, the Court of Justice gives preliminary rulings-on the basis of requests by national courts and tribunals-on the interpretation of the treaties and EU acts and on the validity of EU acts only. Where a question of interpretation or validity ${ }^{2}$ is raised before a national court of last resort, then that court is obliged to refer the matter to the Court of Justice. ${ }^{3}$

Yet, this is not the only form of cooperation involving matters of interpretation and application of EU law within the Union. In a similar way, the EU queries is essentially a mechanism that operates in the context of the EU's multi-level administrative framework and seeks to facilitate the cooperation of national and supranational ombud offices. Simultaneously, there is growing recognition of the importance of ombud offices in promoting accountability, transparency, and good administration; ${ }^{4}$ in other words, they fulfill a "constitutional" role ${ }^{5}$ within, but also beyond, the European Union. Thus, it is essential that scholarly attention on multi-level cooperation in the interpretation and application of EU law is not devoted exclusively to the judicial avenues that have been established therein.

Although the European Ombudsman can respond directly to the national ombud office, the question is usually transferred to the competent EU institution or body. In the vast majority of

\footnotetext{
${ }^{1}$ For a thorough treatment of the topic, see, among other contributions, MORTEN Broberg \& NiELS Fenger, Preliminary ReFERENCES to THe European Court of Justice (2d ed. 2014).

${ }^{2}$ The national court cannot annul an EU act. See ECJ, Case C-314/85, Foto-Frost v. Hauptzollamt Lübeck-Ost, ECLI:EU: C:1987:452 (Oct. 22, 1987), http://curia.europa.eu/juris/liste.jsf?num=C-314/85. Thus, where that court, regardless of its position in the domestic legal order, has doubts about the validity of that act, it must refer the matter to the Court of Justice. See also Albertina Albors-Llorens, Judicial Protection Before the Court of Justice of the European Union, in EUROPEAN UNION LAW 296 (Catherine Barnard \& Steve Peers eds., 2017).

${ }^{3}$ See Consolidated Version of the Treaty on the Functioning of the European Union art. 267(3), Oct. 26, 2012, 2012 O.J. (C 326) 47 [hereinafter TFEU]. There is a very narrow list of exceptions to this rule, most notably when the acte clair doctrine applies. See ECJ, Case C-283/81, Srl CILFIT and Lanificio di Gavardo SpA v. Ministry of Health, ECLI:EU:C:1982:335 (Oct. 6, 1982), para. 16, http:// curia.europa.eu/juris/liste.jsf?num=C-283/81. For further discussion, see, among others, KoEN LENAERTS, IGNACE MASELIS \& Kathleen Gutman, Eu Procedural Law 97-101 (2014). More recently, the CJEU found a breach of Article 267(3) TFEU in the failure, on the part of Conseil d'État, to make a preliminary reference to the CJEU. See ECJ, Case C-416/17, Eur. Comm'n v. French Republic, ECLI:EU:C:2018:811 (Oct. 4, 2018), paras. 100-114, http://curia.europa.eu/juris/liste.jsf?num=C-416/17.

${ }^{4}$ See, e.g., Opinion No. 897/2017 of the European Commission for Democracy Through Law on Principles on the Protection and Promotion of the Ombudsman Institution, CDL-AD(2019)005 (May 3, 2019), https://www.venice.coe.int/webforms/ documents/default.aspx?pdffile=CDL-AD(2019)005-e; Linda ReIF, OMBUDS Institutions, GoOd GovernanCE AND THE International Human Rights System (2d ed. 2020).

${ }^{5}$ See, e.g., Trevor Buck, Richard Kirkham, \& Brian Thompson, The Ombudsman Enterprise and Administrative JUSTICE 23-52 (2011).
} 
cases, this is the European Commission. The Commission provides its response, which is then returned to the European Ombudsman, and from there to the similar domestic office. This exchange between the EU and the national ombud office takes place within an informal network of cooperation, the "European Network of Ombudsmen" (ENO). ${ }^{6}$ Although constituting a longestablished practice since the creation of the ENO in 1996, the European Ombudsman has been publishing anonymized summaries of all queries posed since 2015 on a dedicated website, ${ }^{7}$ thereby enabling a fuller assessment of the cooperation that takes place within this scheme.

From the above brief exposition of the existing arrangements, a matter that is returned to in the next section, certain similarities with the preliminary reference procedure, insofar as the latter concerns the interpretation of EU law, ${ }^{8}$ should already be visible. Although the EU and the national institutions and bodies involved may differ, in both cases a question concerning the correct interpretation and application of EU law is transferred from the domestic to the supranational level. As such, it is a form of extra-judicial cooperation that certainly deserves meticulous examination and scrutiny.

This Article will demonstrate that the EU queries constitute quite a distinctive procedure when compared to the preliminary reference, despite an initial perception of similarity. Several arguments will be developed to this effect, ranging from the degree of informality of the process, the legal nature-binding or non-binding-of the answer that is provided, and its effect on the finality of the dispute, among others. Nevertheless, in terms of broader cooperation between the supranational and domestic levels, this Article will argue that the EU queries process, thanks to its speed and flexibility, may play a crucial role in the coherent and effective application of EU law. More specifically, and despite a number of challenges that are outlined in the penultimate section of this Article, the EU query process may offer interpretative guidance early on in case a problem in the interpretation and application of EU law arises so as to avoid litigation. The EU query process may also serve as a reliable source of information for both the European and the national sides.

This Article therefore makes a significant contribution to the study of extra-judicial cooperation in the EU's multilevel system. It sheds light on the modus operandi of the ENO and the way that EU law is applied at the domestic level by national ombud offices. It further enriches our understanding of the interpretation of EU law by focusing on the Commission's replies in the EU queries. This Article proceeds as follows: The first section provides some background to the establishment of the ENO and, in particular, the EU queries process. The next section examines all of the queries published to date on the European Ombudsman's website, with a view to systemizing their subject matter and assessing the legal characteristics of the given responses. Following this, a comparative assessment with the preliminary reference procedure takes place. Next, the article reflects on the emerging challenges of the EU queries process, as well as the possible way forward. The final section offers some concluding remarks.

\section{B. Background to and Detailed Consideration of the General Arrangements of the EU Queries Process}

The European Ombudsman was established by the Treaty of Maastricht. Under Article 228 TFEU, the Ombudsman can examine complaints or conduct own-initiative inquiries on alleged maladministration in the activities of EU institutions, bodies, offices, and agencies. Although a close examination of the European Ombudsman's mandate cannot be undertaken here, ${ }^{9}$ the crucial point for present purposes is that the European Ombudsman is precluded from receiving complaints against

\footnotetext{
${ }^{6}$ The term "ombudsmen" is not gender-neutral, and therefore the Network should adopt a different name. For further discussion, also about the term "ombudsman" and whether its Scandinavian origins matter, see Varda Bondy \& Margaret Doyle, What's in a Name? A Discussion Paper on Ombud Terminology, in ReSEARCH HandBook ON THE OMbudSMAN 485 (Marc Hertogh \& Richard Kirkham eds., 2018).

${ }^{7}$ See Queries from Members of the Network, Eur. OMBUDSMAN, www.ombudsman.europa.eu/en/european-network-ofombudsmen/queries/en.

${ }^{8}$ It should be emphasized that the validity of an EU act cannot be challenged via the EU queries process anyhow. This is one of the key differences with the preliminary reference, as will also be explained in a subsequent section.

${ }^{9}$ See, e.g., Nikos Vogiatzis, The European Ombudsman and Good Administration in the European Union (2018).
} 
national authorities, even when such authorities are implementing EU law. Such complaints have to be addressed at the domestic level and, so long as a national ombud office exists, they can be dealt with by the similar national office. The treaty provision on this point has remained unchanged; it is only against $E U$ activities that the European Ombudsman is empowered to step in.

However, it was acknowledged early on that a framework of cooperation among all EU ombud offices is needed. Already in 1996, the first office holder, Jacob Söderman, established a rather informal network of cooperation with the aim of connecting the European Ombudsman with national and regional counterparts that dealt with, at the time, Community law complaints. ${ }^{10}$ This network became the ENO and was developed further by the second and third office-holders, Nikiforos Diamandouros and Emily O'Reilly, respectively. In the first meeting, which took place in Strasbourg in September 1996, it was decided that "[T] he cooperation among the bodies involved should be established on an informal and flexible basis and on equal terms. The cooperation would consist of exchanging information, views and advice on Community law matters with the purpose of dealing with citizens' requests and complaints in a more effective way."11 Within the ENO, which at the outset also involved liaison officers, the transfer of complaints from the EU to the national interlocutors, and vice versa, would also take place.

It is important to note that the Commission, Parliament, and Council participated in the aforementioned meeting. This is significant because, as will be shown in a moment, the query procedure has an impact also on these institutions, and in particular the Commission, because the question may be transferred to the competent institution. Thus, on a more general level, the participation of the Commission and other institutions in that meeting, informal as it was, could be deemed to grant further legitimacy to the EU queries scheme. It could even be argued that, because the European Ombudsman or the ENO alone cannot impose obligations to other institutions, the whole query procedure is, in essence, based on the principle of sincere cooperation among institutions, understood in a broader sense. ${ }^{12}$ This means that the other institutions, without being legally obliged, assist the European Ombudsman in the EU query procedure as a gesture of good and sincere cooperation among institutions.

Although the work of the European Ombudsman or other ombud offices is generally associated with maladministration, the scope of the queries is broader, as will be demonstrated in the course of this Article. Yet, some reflections on the term "maladministration" are useful at this juncture. To begin with, it is a term rather difficult to delineate and/or juxtapose with illegality. Also, it was, and still is, not defined in the EU treaties. It may be claimed that maladministration is only part of the work of ombud offices. ${ }^{13}$ In the EU case, however, the first office-holder, Jacob Söderman, opted for a broad definition of maladministration. ${ }^{14}$ It soon became clear that maladministration goes beyond illegality. One of the frequent messages that one reads in many cases and several Annual Reports produced by the Ombudsman-especially by the second office-holder-is that maladministration is "broader than illegality." Thus, it encompasses, but also surpasses, the requirements of the right to good administration ${ }^{15}$ as established by

\footnotetext{
${ }^{10}$ Ombudsman of the European Union, The European Ombudsman Annual Report for 1997, at 10 (Apr. 20, 1998), https:// europa.eu/!FR48nU [hereinafter EOAR 1997].

${ }^{11} I d$. (emphasis added).

${ }^{12}$ The principle of sincere cooperation stems from Article 13(2) of the Treaty on European Union (TEU). It is worth noting, in this respect, that Klamert argued "the preliminary reference procedure, by its very nature as well as by its rules of procedure, embodies the loyalty principle in Union law.” Marcus Klamert, The Principle of Loyalty in EU LaW 14 (2014).

${ }^{13}$ This view seems to have been adopted, for example, by the Council of Europe in Council of Eur., Recommendation CM/ Rec(2019)6 of the Committee of Ministers to Member States on the Development of the Ombudsman Institution, (Oct. 16, 2019), https://rm.coe.int/090000168098392f.

${ }^{14}$ See EOAR 1997 at 23 ("Maladministration occurs when a public body fails to act in accordance with a rule or principle which is binding upon it.").

${ }^{15}$ See further on this point, comparing the European Ombudsman's European Code of Good Administrative Behaviour with the right to good administration, Joana Mendes, Good Administration in EU Law and the European Code of Good Administrative Behaviour (Eur. Univ. Inst., Working Paper No. 2009/09, 2009).
} 
the caselaw of the EU judiciary ${ }^{16}$ and now enshrined in Article 41 of the Charter. ${ }^{17}$ Yet, the EU understanding of maladministration, while serving as a useful starting point, is indeed insufficient to provide a fuller picture of the type of requests that may be submitted to the European Ombudsman. Because the process is initiated from the national level, it is rather the competence of the national office-including its understanding of maladministration and, importantly, as will be explained below, its precise competence or willingness to deal with EU matters-that will eventually inform the type of cases that will reach Strasbourg or Brussels, where the European Ombudsman's office is based. ${ }^{18}$ Indeed, the type of complaints that each office is dealing with can vary across member states. To provide an example, some offices have a clearer focus on human rights or legality. ${ }^{19}$ In that sense, with the above disclaimers in place, the term maladministration will be used hereinafter with a certain degree of liberty to denote the varying remits of the EU and the national ombud offices.

It was in the aforementioned seminar in 1996 in Strasbourg that the EU queries process was agreed upon as an informal mechanism of cooperation. The European Ombudsman would receive such queries "about Community law" and would either reply directly or transfer the request to one of the EU institutions or bodies. ${ }^{20}$ In 1997, the two queries that were received by the office were transferred to the Commission. In 2007, the ENO adopted a "statement," a non-binding document, which sought to provide guidance and raise awareness about the work of the European Ombudsman and national ombud offices in the sphere of EU law. ${ }^{21}$ Therein, it was explained that national and regional offices "may ask the European Ombudsman for written answers to queries about EU law and its interpretation, including queries that arise in their handling of specific cases." ${ }^{22}$ In the 2008 Annual Report it was further explained that "the purpose of the Statement is to make the EU dimension of ombudsmen's work better known and to clarify the service that they provide to people who complain about matters within the scope of EU law." 3

Thus, the process would help the national offices in the correct application of EU law, but would also provide further support, where such was needed, in order for the national administration to meet its EU law obligations. ${ }^{24}$ The possibility for requests on interpretation of EU law from a national office to the European office, and the resemblance to the preliminary reference, has prompted commentary that a hierarchical structure could be established, which could possibly jeopardize the "equalitarian relationship between the European Ombudsman and his peers." 25

If there is one particularly striking feature about the EU queries process, it is its marginal, possibly non-existent, degree of regulation. This may be explained by the purposeful informality of

\footnotetext{
${ }^{16}$ See Herwig Hofmann \& Bucura Mihaescu, The Relation Between the Charter's Fundamental Rights and the Unwritten General Principles of EU Law: Good Administration as the Test Case, 9 EuR. ConsT. L. Rev. 73 (2013).

${ }^{17}$ On Article 41 of the Charter, see, among others, EMILIE Chevalier, Bonne Administration et Union EURopÉENnE (2014).

${ }^{18}$ The seat of the European Ombudsman is in Strasbourg. For obvious reasons, however, a significant number of staff members are based in the Brussels office, and the European Ombudsman herself splits her time across both locations.

${ }^{19}$ For further discussion, see, for example, Päivi Leino, The Wind is in the North: The First European Ombudsman (19952003), 10 EUR. PUb. L. 333, 337-39 (2004).

${ }^{20}$ EOAR 1997 at 282.

${ }^{21}$ European Ombudsman, About the European Network of Ombudsmen, Statement Adopted at the Sixth Seminar of the National Ombudsmen of EU Member States and Candidate Countries (Oct. 14-16, 2007), www.ombudsman.europa.eu/ en/european-network-of-ombudsmen/about/en.

${ }^{22} I d$. (emphasis added).

${ }^{23}$ Ombudsman of the European Union, The European Ombudsman Annual Report for 2008, at 77 (Apr. 20, 2009), https:// europa.eu/!kN69fQ [hereinafter EOAR 2008] (emphasis added). The need for queries to fall within the scope of EU law is a matter returned to below.

${ }^{24}$ See Nikiforos Diamandouros, The European Ombudsman and the Application of EU Law by the Member States, 1 REV. Eur. Admin. L. 5, 27-28 (2008).

${ }^{25}$ Alexandros Tsadiras, Rules of Institutional "Flat-Sharing": The European Ombudsman and His National Peers, 33 EUR. L. REV. 101, 108-09, 113 (2008). As Tsadiras notes at page 108, a proposal for a formal preliminary reference mechanism, submitted by the Danish Ombudsman in the context of discussions on the European Ombudsman's Statute, was rejected.
} 
the network arrangements. Beyond the treaty text, which is silent on this matter, neither the European Ombudsman's Statute ${ }^{26}$ nor the Implementing Provisions ${ }^{27}$ provide any further details about the scheme. The European Ombudsman's website, where all the queries from 2015 to date have been published - and which are further analyzed and systemized in the following sectionstates that these are "about EU issues that have arisen during their inquiries." ${ }^{28}$ However, as the above statement explains, national offices are in principle entitled to submit queries on EU-related matters that do not necessarily arise in the context of a specific case or complaint. In several Annual Reports, the formulation "including queries that arise in their handling of specific cases" can be found. ${ }^{29}$ This broad formulation might also have been chosen in light of the different competences of the national or regional ombud offices, as explained above, including the capacity, or lack thereof, to start an own-initiative or strategic investigation outside the context of a specific case or complaint. ${ }^{30}$

Next, the formulation "about EU issues" raises the question as to whether the matter for which a legal opinion is requested should fall within areas where Member States and national authorities are implementing EU law or are acting within the scope of EU law. ${ }^{31}$ In other words, one may be entitled to pose the question whether this formulation implies a broader approach to the Charter's field of application ${ }^{32}$ or the Court's caselaw on that matter. ${ }^{33}$ The earlier quote from the 2008 Annual Report already appears to provide an answer in the negative. ${ }^{34}$ It is not for the European Ombudsman-or for the EU for that matter- to decide whether, and if so the terms under which, the national interlocutor will have competence to examine EU-related matters, but there is a reasonable expectation to do so. A study completed in 2005 demonstrated that almost all national offices that participated in the study applied EU law "to some extent." ${ }^{5}$ In addition, the aforementioned Statement recalls the wide variety of mandates of the national ombud offices, and

\footnotetext{
${ }^{26}$ Decision of the European Parliament of 18 June 2008 Amending Decision 94/262/ECSC, EC, Euratom on the Regulations and General Conditions Governing the Performance of the Ombudsman's Duties, 2008 O.J. (L 189). The only indirect reference to the network, but not the queries scheme, stems from Article 5(1), which states that "[i]n so far as it may help to make his enquiries more efficient and better safeguard the rights and interests of persons who make complaints to him, the Ombudsman may cooperate with authorities of the same type in certain Member States provided he complies with the national law applicable." Likewise, no reference to EU queries is to be found in the new proposed Statute by the European Parliament, and its revised provision (Article 7(1)). See Resolution on a Draft Regulation of the European Parliament Laying Down the Regulations and General Conditions Governing the Performance of the Ombudsman's Duties, Eur. PArL. Doc. P8_TA(2019)0080 (2019), www.europarl.europa.eu/doceo/document/TA-8-2019-0080_EN.pdf.

${ }^{27}$ See European Ombudsman, Decision of the European Ombudsman Adopting Implementing Provisions (2016), www. ombudsman.europa.eu/en/legal-basis/implementing-provisions/en. Article 12 of the Implementing Provisions provides that the "Ombudsman may cooperate with ombudsmen and similar bodies in the Member States, including through the European Network of Ombudsmen.”

${ }^{28}$ See EUR. OMbudsman, supra note 7.

${ }^{29}$ This wording is to be found in Annual Reports subsequent to the statement of 2007 (emphasis added). All of the Annual Reports of the European Ombudsman can be found at www.ombudsman.europa.eu/en/our-strategy/annual-reports.

${ }^{30}$ This power is clearly granted to the European Ombudsman under Article 228 TFEU-and the present office holder, in particular, has resorted frequently to this instrument-but it is not a given across all ombud offices in the EU.

${ }^{31}$ See ECJ, Case C-617/10, Åklagaren v. Hans Åkerberg Fransson, ECLI:EU:C:2013:105 (Feb. 26, 2013), paras 17-19, http:// curia.europa.eu/juris/liste.jsf?num $=\mathrm{C}-617 / 10$.

${ }^{32}$ See Charter of Fundamental Rights of the European Union art. 51, Oct. 26, 2012, 2012 O.J. (C 326) 391.

${ }^{33}$ When Member States are acting within the scope of EU law, and the caselaw arising thereof, is a matter that cannot be examined in this contribution. See, e.g, Michael Dougan, Judicial Review of Member State Action Under the General Principles and the Charter: Defining the "Scope of Union Law", 52 Common MкT. L. Rev. 1201 (2015).

${ }^{34}$ See EOAR 2008.

${ }^{35}$ See Rick Lawson (General Rapporteur), General Report of the Seminar: The Role of Ombudsmen and Similar Bodies in the Application of EU Law, in The Role of Ombudsmen and Similar Bodies in the Application of EU Law, 5th Seminar of the National Ombudsmen of the EU Member States and Candidate Countries (2005), Annex III, p. 77, https://op.europa.eu/en/ publication-detail/-/publication/3777b229-1e54-49a9-a755-42e16bbdc953/language-en.
} 
also underlines that they "deal with complaints against public authorities of the Member States, including complaints that relate to activities that are within the scope of EU law." 36

In any event, if the EU-related matter falls within the competence of the national office, a question arises as to whether that office can submit a query to the European Ombudsman that may have some remote connection to EU law which, however, according to the case-law of the CJEU, cannot be deemed to fall within the "scope of EU law." The answer should be, in principle, in the negative, in that, whereas such query might indeed be submitted, an opinion may not be provided by either the Commission or the European Ombudsman on the basis that the matter does not fall within Union law. It would indeed be ill-suited for the European Ombudsman-or effectively by the Commission for that matter-to inappropriately expand the scope of EU law via this rather informal process. Besides, the above statements and indications in the Annual Reports confinerightly, it is submitted-the field of cooperation to matters within the scope of the application of EU law. This approach was confirmed in a query published in the Annual Report of $2007 .{ }^{37}$ More specifically, the question was whether an EU citizen who was born in France and served in the French army but subsequently relinquished French citizenship and acquired Luxembourgish citizenship, could be eligible for a veteran pension in France. The Ombudsman of Luxembourg asked whether this case could qualify as discrimination on the basis of nationality. The European Ombudsman, who replied directly in this case, took the questionable view that although the case seemed prima facie to have a link with the exercise of the free movement of persons, the situation of the complainant did not seem to fall within the scope of the application of Community law, as in essence it concerned the eligibility criteria for a national pension. Whether the Ombudsman's view was legally correct is not addressed here; if anything, the Annual Report only provides a brief summary of the case. What this case does demonstrate, though, is that the European Ombudsman would deal with a query on its substance only if the Member State concerned is acting within the scope of EU law according to the Ombudsman's, or possibly the Commission's, assessment. Getting this question always "right" is, of course, far from a straightforward matter. A study authored by Spaventa concerning the treatment of petitions by the Commission and submitted to it by the Committee on Petitions of the European Parliament found that the Commission largely applied correctly the caselaw of the Court on Article 51 of the Charter. ${ }^{38}$ As it is also shown later on, in Section C of this Article, all the summaries of queries published on the European Ombudsman's dedicated website appear to fall within the scope of the application of EU law.

Nevertheless, ENO membership is not confined to national offices from the Member States. Beyond the Committee of Petitions, which is inter alia the parliamentary committee responsible for relations with the European Ombudsman, ${ }^{39}$ the ENO also consists of ombud offices from applicant countries and non-EU Member States. ${ }^{40}$ If it is acceptable that these offices may also submit a query — and nothing appears to suggest that they should not be able to do so-and also that the query may not necessarily concern the resolution of a specific case, as was argued above and as the Statement also indicates, then it is possible that a query be submitted by an office that is

\footnotetext{
${ }^{36}$ European Ombudsman, supra note 21 (emphasis added).

${ }^{37}$ Summary of Query Q1/2007/ELB Submitted by the Ombudsman of Luxembourg, published in Ombudsman of the European Union, The European Ombudsman Annual Report for 2007, at 93 (Mar. 10, 2008), https://europa.eu/!TH46dg [hereinafter EOAR 2007].

${ }^{38} \mathrm{See}$ The Interpretation of Article 51 of the EU Charter of Fundamental Rights: The Dilemma of Stricter or Broader Application of the Charter to National Measures, Eur. PARL. Doc. PE 556.930 (2016), https://www.europarl.europa.eu/ RegData/etudes/STUD/2016/556930/IPOL_STU(2016)556930_EN.pdf.

${ }^{39}$ See European Parliament, Rules of Procedure, Annex VI, Powers and Responsibilities of Standing Committees, XX Committee on Petitions, p. 159 (February 2020), www.europarl.europa.eu/doceo/document/RULES-9-2020-02-03_EN.pdf.

${ }^{40} \mathrm{See}$ Members of the European Network of Ombudsmen, EUR. OMBUDSMAN, www.ombudsman.europa.eu/en/europeannetwork-of-ombudsmen/members/all-members.
} 
not bound by EU law at the time of submission. ${ }^{41}$ This demonstrates the flexibility of the EU queries process and that it does not operate on a purely legalistic basis.

In addition, the query system has operated for years under rather opaque terms, much like the ENO itself more generally. In the first two decades of the European Ombudsman's operation, how such queries have been presented in the Annual Reports has varied enormously. At best, brief summaries of cases transferred to the European Ombudsman have featured in the Annual Reports; ${ }^{42}$ elsewhere, the report would mention the overall number of queries received, but would only provide a summary of one or more "examples." ${ }^{33}$ In other Reports, the office would merely state the number of queries received and their origin without providing any further details or examples-for instance, about the subject matter, the reply, or outcome of the initial case. ${ }^{44}$ In certain Reports a brief explanation of the origin and subject matter would simply be provided, ${ }^{45}$ and in others there is no information at all. ${ }^{46}$ The reason behind this asymmetry is that the consent of the national office would usually be a requirement before the release of further information. It was only in the 2011 seminar in Copenhagen when it was agreed that "information about these queries will be available to the general public on the European Ombudsman's website." 47 This call was eventually materialized by Emily O'Reilly, and further information is available on the European Ombudsman's website, covering the period since 2015.

O'Reilly has also decided to expedite the query procedure. The aim is for the process to be completed within twenty working days, unless the Commission needs more time to prepare its reply. ${ }^{48}$ This should "ensure responses-obtained from the EU institutions-arrive in time for national [ombud offices] to use them in their own inquiries." ${ }^{2}$ The full query and the Commission's reply, however, appear to be accessible only to ENO members, through the "ENONET". 50

The particular features of the EU query process will be returned to below, where a comparative assessment with the preliminary reference will take place. For now, a further distinction appears essential: The EU queries should be distinguished from "parallel inquiries," which also appear on the ENO's website. These are inquiries undertaken jointly by the European Ombudsman and her or his national interlocutors on matters that involve both the EU and national administrations, with a view to compiling reports that would be of broader relevance and use. The European Ombudsman coordinates the effort, and participation in such inquiries is voluntary. Examples

\footnotetext{
${ }^{41}$ The following scenario may be envisaged: A national ombud office of an applicant country submits a query to the European Ombudsman with a view to clarifying the legal framework for future work or reference.

${ }^{42}$ See, e.g., Ombudsman of the European Union, The European Ombudsman Annual Report for 2006, at 102 (Feb. 22, 2007), https://europa.eu/!Mp63mv.

${ }^{43}$ See, e.g., EOAR 2007 at $25,93$.

${ }^{44}$ See, e.g., Ombudsman of the European Union, The European Ombudsman Annual Report for 2005, at 31 (Mar. 13, 2006), https://europa.eu/!Hn34WK.

${ }^{45}$ See, e.g., Ombudsman of the European Union, The European Ombudsman Annual Report for 2011, at 65-66 (Feb. 12, 2012), https://europa.eu/!gN49GF.

${ }^{46}$ See, e.g., Ombudsman of the European Union, The European Ombudsman Annual Report for 2001 (Apr. 8, 2002), https:// europa.eu/!nv67Gg; Ombudsman of the European Union, The European Ombudsman Annual Report for 2013 (Mar. 31, 2014), https://europa.eu/!gK39um; Ombudsman of the European Union, The European Ombudsman Annual Report for 2014 (Feb. 16, 2015), https://europa.eu/!Uh43rc.

${ }^{47} I d$. at 8 . In the same Annual Report, it was explained that the earlier Forum would be replaced with a new "Extranet," an internal platform accessible only to ENO members.

${ }^{48}$ European Ombudsman, Manual on Case Handling Procedures, at 33 (on file with the authors); European Ombudsman, Queries from Members of the Network (on file with the authors). These documents indicate that the author of the query is invited to submit observations within seven days from the receipt of the reply. Emily O'Reilly presented her proposals in the context of the initiative "Reforming the European Network of Ombudsmen."

${ }^{49}$ Ombudsman of the European Union, The European Ombudsman Annual Report for 2015, at 26 (May 2, 2016), https:// europa.eu/!kH46uR.

${ }^{50} \mathrm{This}$ is a platform that can be accessed by ENO members only. Interestingly, the author of the query should also indicate their agreement in order for the query to be published therein.
} 
have included the forced return of irregular migrants and human rights violations; ${ }^{51}$ "how the European Commission ensures that the fundamental rights enshrined in the Charter. . . are complied with when EU cohesion policy is implemented by Member States"; 52 and effective complaint mechanisms for the European Structural and Investment Funds. ${ }^{53}$

\section{A Systematic Classification of the EU Queries Published on the European Ombudsman's Website}

This section aims to systemize the EU queries published on the Ombudsman's website from 2015 to date ${ }^{54}$ and assess the legal characteristics of the responses given. It is understood that all of the submitted queries, or at least summaries thereof, that were received since 2015 have been published on the European Ombudsman's website. The overall number of such queries is twentyeight. In most years, three or four queries were submitted, with a peak in 2016 and 2017, where the yearly queries were eight and six, respectively. These figures indicate that the query process has yet to realize its full potential; this is a matter returned to below. ${ }^{55}$

Looking at the geographic distribution, the queries during the period of reference came from thirteen Member States, ${ }^{56}$ with a notable absence of big Member States such as Germany, France, and the UK. ${ }^{57}$ This means that less than half of the Member States have made use of the query procedure. The subject matters of the queries cover a wide range of EU law fields: Eleven concerned the functioning of the internal market; ${ }^{58}$ five concerned environmental law matters; ${ }^{59}$ six

\footnotetext{
${ }^{51}$ See Decision of the European Ombudsman Closing Her Own-Initiative Inquiry OI/9/2014/MHZ Concerning the European Agency for the Management of Operational Cooperation at the External Borders of the Member States of the European Union (Frontex) (May 4, 2015), https://europa.eu/!tx77dv. All European Ombudsman cases mentioned in this Article can be accessed at www.ombudsman.europa.eu.

${ }^{52}$ Decision of the European Ombudsman Closing Her Own-Initiative Inquiry OI/8/2014/AN Concerning the European Commission (May 11, 2015), https://europa.eu/!rQ46NW.

${ }^{53}$ See Decision on Strategic Initiative SI/3/2018/JN: Effective Complaint Mechanisms for Matters Concerning European Structural and Investment Funds - Follow-Up to OI/8/2014/AN (Jul. 18, 2019), https://europa.eu/!NV48hx.

${ }^{54}$ This study considers all of the queries that were published on the ENO website until the end of November 2020. For readability purposes, all subsequent Queries will be referred to simply by their Query Identifier. Queries may be accessed at https://www.ombudsman.europa.eu/en/european-network-of-ombudsmen/queries/en.

${ }^{55}$ Out of the twenty-eight queries, twenty-four have been closed and a comprehensive summary is published on the dedicated website. Four are still open with little information available.

${ }^{56}$ Four from Belgium (Q2/2015/DR, Q6/2017/EIS, Q4/2018/JAP, and Q1/2020/JAP), Spain (Q3/2016/JAP, Q3/2017/MDC, Q1/2019/JF, and Q3/2020/JF), and Austria (Q1/2015/JAS, Q4/2016/JN, Q5/2017/JN, and Q2/2018/EIS); three from Ireland (Q3/2015/JAP, Q2/2016/JAP, and Q1/2018/EIS) and Malta (Q9/2016/MDC, Q7/2016/MDC, and Q6/2016/EIS); two from Denmark (Q3/2018/EIS and Q2/2019/MOM) and Italy (Q1/2016/EIS and Q3/2019/MDC); and one from Latvia (Q4/ 2020/MHZ), Portugal (Q2/2020/JF), Bulgaria (Q1/2017/JAP), Poland (Q2/2017/JAP), Estonia (Q4/2017/EIS), and Finland (Q8/2016/EIS), respectively.

${ }^{57}$ The UK withdrew from the EU on January 31, 2020 and the transition period will last until December 31, 2020. During the transition period, although the UK is no longer a Member State, all institutions, bodies, offices and agencies of the EU continue to hold the powers conferred upon them by EU law in relation to the UK and to natural and legal persons residing, or established in, the UK. See Agreement on the Withdrawal of the United Kingdom of Great Britain and Northern Ireland from the European Union and the European Atomic Energy Community art. 131, Jan. 24, 2020, 2019 O.J. (C 384I).

${ }^{58}$ See Q1/2015/JAS from Austria on the VAT Directive; Q4/2016/JN from Austria on the free movement of services; Q3/ 2016/JAP from Spain on public procurement; Q2/2016/JAP on the qualification of drivers; Q1/2016/EIS from Italy on crossborder reimbursement of medical expenses; Q1/2017/JAP from Bulgaria on dual quality products; Q2/2018/EIS from Austria on family benefits in cross-border situations; Q3/2019/MDC from Italy on standards for driving seats; Q4/2020/MHZ from Latvia on banking services; and Q1/2019/JF and Q3/2020/JF from Spain on rules concerning unaccompanied minors during commercial flights.

${ }^{59}$ See Q9/2016/MDC from Malta on bird protection; Q7/2016/MDC on public participation in environmental matters; Q6/ 2016/EIS from Malta on access to environmental information; Q3/2018/EIS from Denmark on access to environmental information; and Q2/2019/MOM from Denmark on access to environmental information.
} 
concerned migration, asylum, and the rules on visas; ${ }^{60}$ four concerned the area of justice; ${ }^{61}$ and two concerned the rules on EU funding. ${ }^{62}$

Regarding the type of questions posed, the vast majority of them concern the interpretation of EU law and also the compatibility of national rules with EU law. For example, national ombud offices have asked how to reconcile the meaning of two EU law provisions that appear to be contradictory. ${ }^{63}$ Other interpretation questions have concerned the scope of application of EU law provisions, ratione temporis or ratione materiae. For example, a query from the Irish Ombudsman concerned whether a regulation that had in the meantime been repealed would continue to apply for cases that occurred while it was still in force. ${ }^{64}$ The Austrian Ombudsman Board enquired on the material scope of the GDPR and whether it also covers the activities of national ombud offices. ${ }^{65}$ Many questions have concerned the definition of a legal term and whether the facts in the case at hand would fall under this definition. For instance, the Danish Parliamentary Ombudsman asked whether the information on the renewal of a license to serve alcohol in a pub could fall under the definition of environmental information. ${ }^{66}$ In certain cases, national ombud offices have enquired whether existing EU rules have left any discretion to national authorities to regulate certain issues on their own. For example, the regional Ombudsman of Aragon, Spain asked whether EU public procurement rules would allow national authorities to exclude abnormally low tenders coming from publicly funded entities. ${ }^{67}$

A series of questions referred to the national transposition or implementation of EU law and expressed concerns as to whether this was in conformity with EU rules. ${ }^{68}$ In the context of bad transposition, the question of the possible direct effect of a provision of a Directive was also brought up. ${ }^{69}$ Two queries reported problems concerning the practical implementation of EU law: Excessive delays in handling visa applications and family benefits in cross border situations,

\footnotetext{
${ }^{60}$ See Q2/2015/DR from Belgium on asylum; Q3/2017/MDC from Spain on the handling of complaints by FRONTEX; Q6/ 2017/MDC from Belgium on the Family Reunification Directive 2003/86/EC; Q4/2018/JAP from Belgium on entry visas for non-EU family members; Q1/2020/JAP from Belgium on third country nationals' residence rights; and Q2/2020/JF from Portugal on the Dublin Regulation.

${ }^{61}$ See Q8/2016/EIS from Finland on the accessibility of restaurants in trains for persons with a disability; Q4/2017/EIS from Estonia on gathering statistical data on IT access of the elderly (equality policy); Q5/2017/JN from Austria on the applicability of the GDPR on national ombud offices; and Q2/2017/JAP from Poland on the Victims' Rights Directive (Directive 2012/29/EU).

${ }^{62}$ See Q3/2015/JAP and Q1/2018/EIS, both from Ireland concerning funds in the agriculture field.

${ }^{63}$ See Q4/2020/MHZ from the Latvian Ombudsman on the apparent contradiction between the Anti-Money Laundering Directive and the Payment Accounts Directive and Q2/2016/JAP from the Irish Ombudsman on the apparent contradiction of two provisions of a Directive on the qualification and training of drivers for certain vehicles.

${ }^{64}$ See Q3/2015/JAP.

${ }^{65}$ See Q5/2017/JN. See also Q1/2015/JAS from the Austrian Ombudsman Board as to whether an activity is covered by the VAT Directive.

${ }^{66}$ See Q3/2018/EIS (the complainant alleged "massive noise problems and odours as a result of intrusive tobacco smoke coming from the pub"). See also Q1/2018/EIS from the Irish Ombudsman on the meaning of the phrase "no more than 40 years old" for the purposes of agricultural funding; Q2/2015/JAP from the Belgian Federal Ombudsman on the definition of the term "to abscond' in EU asylum law."

${ }^{67}$ See Q3/2016/JAP; See also Q3/2019/MDC from the regional Ombudsman of Tuscany on whether allowing the modification of driver seats to allow for swivel car seats is left to the discretion of national authorities or not.

${ }^{68}$ See Q7/2016/MDC from the Maltese Commissioner for Environment, who forms part of the Parliamentary Ombudsman of Malta, on whether Malta has breached the Aarhus Directive on public participation; Q6/2016/EIS from the above office on the apparent bad transposition of EU rules on road safety; Q9/2016/MDC from the Maltese Parliamentary Ombudsman on whether Maltese law was compatible with the EU provisions on the conservation of wild birds; and Q4/2016/JN from the Austrian Ombudsman Board on whether a municipal practice was breaching the EU principle of non-discrimination.

${ }^{69}$ See Q1/2020/JAP from the Belgian Federal Ombudsman on whether a provision of the Directive on the entry and residence of third country nationals for purposes of studies etc. could have direct effect.
} 
respectively, and whether such delays would go against the spirit of the respective EU law directives in the absence of explicit deadlines. ${ }^{70}$

Among the interpretation questions submitted to the European Ombudsman within the period of reference, there have been no questions explicitly contesting the validity of EU rules. However, there has been one query where the Finnish Parliamentary Ombudsman expressed concerns about the compatibility of EU rules on rail passengers' rights with the UN Convention on the Rights of Persons with Disabilities (UNCRPD). More specifically, the national office found problematic the fact that the relevant EU rules do not contain mandatory requirements regarding wheelchair space in restaurant cars. ${ }^{71}$ It is established caselaw that non-conformity with an international law obligation of the EU may indeed render an EU secondary law provision invalid, as long as the international provision is sufficiently precise and unconditional. ${ }^{72}$ The UNCRPD was found by the CJEU not to meet these conditions. ${ }^{73}$ Nevertheless, according to the caselaw, the primacy of international agreements concluded by the European Union over provisions of secondary legislation means that such provisions must, so far as is possible, be interpreted in a manner that is consistent with those agreements. ${ }^{74}$

Questions on the interpretation of EU law are often coupled with queries of a wider scope, such as requests for information or enquiries about the Commission's intention to revise the existing rules or revisit existing policy choices. For example, the Estonian office (the Estonian Chancellor of Justice) asked if the Commission had any statistics on access to ICT services among citizens aged above seventy-five and whether it was planning to invite Member States to gather such data in the future. ${ }^{75}$ The Belgian Federal Ombudsman, echoing concerns of a number of offices that were expressed during an ENO conference in 2017, enquired whether the Commission was planning to revise existing guidance to Member States on family reunification in light of developments in the context of the migration crisis. ${ }^{76}$ Furthermore, in certain instances, national ombud offices have used the EU query procedure as a way to make the Commission aware of a problem and ask how the Commission intends to act. For example, the Bulgarian Ombudsman brought to the attention of the Commission the issue of different food quality standards of the products of the same company depending on the Member State it targets. ${ }^{77}$ The Austrian Ombudsman Board made a query to report that there were significant delays when two Member States had to decide which one should pay family and child benefits in cross-border situations and that the relevant EU rules on provisional payment of benefits until there is a final settlement became dead letter in practice. ${ }^{78}$

Regarding the way the EU queries are posed, there is no uniformity. Certain queries contain a detailed description of the national case at stake or the national provisions that might conflict with $\mathrm{EU}$ law, ${ }^{79}$ whereas in other instances the interpretation question is posed with little background

\footnotetext{
${ }^{70}$ See Q4/2018/JAP from the Belgian Ombudsman on visa applications and Q2/2018/EIS from the Austrian Ombudsman Board concerning family benefits in cross-border situations.

${ }^{71}$ See Q8/2016/EIS. All answers to the queries are addressed in subsequent paragraphs of this section.

${ }^{72}$ See ECJ, Case C-363/12, Z. v. A Gov't Dep't and the Bd. of Mgmt. of a Cmty. Sch., ECLI:EU:C:2014:159 (Mar. 18, 2014), paras. 89, 90, http://curia.europa.eu/juris/liste.jsf?num=C-363/12; ECJ, Case C-356/12, Wolfgang Glatzel v. Freistaat Bayern, ECLI:EU:C:2014:350 (May 22, 2014), para. 69, http://curia.europa.eu/juris/liste.jsf?num=C-356/12.

${ }^{73}$ Glatzel, Case C-356/12 at para. 69 ("[S]ince the provisions of the UN Convention on Disabilities are subject, in their implementation or their effects, to the adoption of subsequent acts of the contracting parties, the provisions of that convention do not constitute, from the point of view of their content, unconditional and sufficiently precise conditions which allow a review of the validity of the measure of EU law in the light of the provisions of that convention.").

${ }^{74} \mathrm{See}$ id. at para. 70; ECJ, Case C-61/94, Comm'n of the Eur. Communities v. Fed. Republic of Germany, ECLI:EU: C:1996:313 (Sept. 10, 1996), para. 52, http://curia.europa.eu/juris/liste.jsf?num=C-61/94.

${ }^{75} \mathrm{See}$ Q4/2017/EIS.

${ }^{76}$ See Q6/2017/MDC.

${ }^{77}$ See Q1/2017/JAP.

${ }^{78}$ See Q2/2018/EIS.

${ }^{79}$ See for example Q7/2016/MDC from the Maltese Commissioner for Environment concerning citizens' rights to participate in the formulation of planning policies under the Aarhus Convention.
} 
information, or at least presented like that in the public summary of the case. ${ }^{80}$ This means that it is not always justified why the national ombud office needs the interpretation guidance that she or he is seeking in order to solve a specific case.

All published queries within the period of reference were transferred from the Ombudsman to the Commission, with the exception of one question, which was forwarded to an EU decentralized agency, FRONTEX. The reason for passing the question to FRONTEX was because the query concerned the practice of that specific agency regarding the treatment of complaints by citizens. ${ }^{81}$ In the remaining cases, when the reply was given by the Commission, it was generally not specified which exact service within the Commission had replied, ${ }^{82}$ with the exception of one query, where it was explicitly mentioned that the Directorate-General in charge of mobility and transport of the Commission (DG MOVE) gave the reply. ${ }^{83}$ In the period of reference, no reply was given directly by the Ombudsman, although, as mentioned above, this possibility exists.

Having examined the scope of the submitted queries, attention will now shift to the answers that were provided. The nature of the reply depends on the type of question posed. The replies on the interpretation of EU law are drafted in a non-authoritative way, so as not to create the impression that they are legally binding. In certain instances, the reply contains an explicit disclaimer added by the Commission that according to the Treaties, the CJEU is the only competent authority to deliver binding interpretation of EU law. ${ }^{84}$ This statement from the Commission fully accords with a long-established position by the European Ombudsman that any interpretation that may be provided in the context of an inquiry does not negate the fact that the highest authority is the CJEU. In a nutshell, the Commission's replies reflect its view on the interpretation of an EU law provision, based on existing caselaw and the application of general principles of law, while using the classic legal interpretation methods, but without prejudging how the law might be ultimately interpreted by the Court. For example, in a query from the Danish Parliamentary Ombudsman on whether the renewal of a license to serve alcohol in a pub could fall under the definition of environmental information, the Commission replied in the negative based on existing caselaw by the Court of Justice. ${ }^{85}$ More specifically, the Commission argued that, according to the caselaw, the concept of environmental information needs to have an actual or foreseeable link with the environment; a license to serve alcohol in a pub does not, according to the Commission, fulfill this criterion of a "direct or foreseeable" link.

Furthermore, the Commission also replies using existing soft law guidance already provided by the Commission or expert groups. ${ }^{86}$ For instance, the Belgian Federal Ombudsman enquired on the indicative time to process entry visas for non-EU family members. ${ }^{87}$ The relevant legislation was silent in this respect, but the Commission replied with reference to the Handbook for the Processing of Visa Applications, as adopted by a Commission Implementing Decision, ${ }^{88}$ which contains implementation guidance for Member States. In another case, the Belgian Federal

\footnotetext{
${ }^{80}$ See, e.g., Q2/2015/DR (regarding the interpretation of the term "to abscond" in EU asylum law).

${ }^{81}$ See Q3/2017/MDC.

${ }^{82}$ The documents cited at supra note 48 specify that the European Ombudsman will usually send the query to the SecretariatGeneral of the Commission (or any other EU institution, body or agency concerned). The Secretariat-General consults with the competent Directorate-General within the Commission and provides the reply to the European Ombudsman.

${ }^{83} \mathrm{See}$ Q2/2016/JAP.

${ }^{84}$ See Q1/2020/JAP; Q3/2015/JAP.

${ }^{85}$ See Q3/2018/EIS.

${ }^{86}$ On expert groups set up by the Commission in order to advise on policy matters, see Commission Decision of 30.5 .2016 Establishing Horizontal Rules on the Creation and Operation of Commission Expert Groups, 2016 C(2016) 3301 final, https:// ec.europa.eu/transparency/regexpert/PDF/C_2016_3301_F1_COMMISSION_DECISION_EN.pdf. For further discussion, see, among others, Julia Metz, The European Commission, Expert Groups, and the Policy Process: Demystifying TECHNOCRATIC GOVERNANCE (2015).

${ }^{87}$ See Q4/2018/JAP.

${ }^{88}$ See Commission Implementing Decision of 28.1.2020 Amending Commission Decision C(2010) 1620 Final as Regards the Replacement of the Handbook for the Processing of Visa Applications and the Modification of Issued Visas (Visa Code
} 
Ombudsman had asked whether a provision of Directive 2016/801 on the Conditions of Entry and Residence of Third Country Nationals for the Purposes of Studies, et cetera, ${ }^{89}$ could have direct effect in case it was not correctly transposed by a Member State. ${ }^{90}$ The Commission replied by referring to the discussions of the Expert Group on Legal Migration, composed of representatives of the Commission and Member States, wherein it was concluded that the relevant provision of the directive is clear, precise, and unconditional and can thus have direct effect. The Commission also explicitly added the disclaimer that only the CJEU can deliver legally binding interpretation of Union law.

Where relevant caselaw or other type of interpretation guidance, as aforementioned, is not available, the Commission normally replies using the classic methods of legal interpretation; ${ }^{91}$ in essence, a systematic interpretation of the different relevant provisions, ${ }^{92}$ literal, ${ }^{93}$ or teleological interpretation. ${ }^{94}$ For instance, to the reply of the Austrian Ombudsman Board as to whether an activity is covered by the VAT Directive, the Commission replied that whatever is not explicitly excluded is a contrario covered by the scope of application of the Directive. ${ }^{95}$ To the question of the Irish Ombudsman on the meaning of the phrase "no more than 40 years old" for the purposes of agricultural funding, the Commission replied on the basis of literal interpretation-that those who are forty years old are included by the scope of the provision. ${ }^{96}$ In a query from the Belgian Federal Ombudsman on the interpretation of the term "to abscond" in EU asylum law, the Commission noted that the aforementioned term was not defined in the relevant legislation and thus had to be interpreted in its ordinary sense, within its context, and taking into account the purpose of the legislation; ${ }^{97}$ the principle of an individual assessment on a case-by-case basis should equally be applied to determine whether a person has effectively absconded.

Depending on the way a question is formulated, the Commission might go beyond strict legal interpretation and may acknowledge the need to take into account certain particular circumstances in the future when revising the relevant legislative document. For example, in a query, the Latvian Ombudsman asked if there are any possible alternative mechanisms that would allow consumers who cannot open a bank account with basic features due to non-compliance with antimoney-laundering legislation to undertake essential payment transactions. ${ }^{98}$ The Commission replied that no alternatives are available but committed to take into account the query for future revision of the respective directive. In a similar vein, the Commission committed to address the

Handbook I), C(2020) 395 final, https://ec.europa.eu/home-affairs/sites/homeaffairs/files/c-2020-395-commissionimplementing-decision_en.pdf.

${ }^{89}$ Directive 2016/801, of the European Parliament and of the Council of 11 May 2016 on the Conditions of Entry and Residence of Third-Country Nationals for the Purposes of Research, Studies, Training, Voluntary Service, Pupil Exchange Schemes or Educational Projects and Au Pairing, 2016 O.J. (L 132) 21-57.

${ }^{90}$ See Q1/2020/JAP.

${ }^{91}$ On the legal argumentation method, see, among others, Robert AlEXY, THEORIE DER JURISTISCHEN ARGUMENTATION 273 (3d ed. 1996) andThomas Möllers, Juristsiche Methodenlehre 113 (3d ed. 2020). See also, regarding the CJEU, Koen Lenaerts \& José A. Gutiérrez-Fons, To Say What the Law of the EU Is: Methods of Interpretation and the European Court of Justice (Eur. Univ. Inst., Working Paper No. 2013/09, 2013).

${ }^{92}$ See Q4/2020/MHZ from the Latvian Ombudsman on the apparent contradiction between the Anti-Money Laundering Directive and the Payment Accounts Directive; Q2/2016/JAP from the Irish Ombudsman on the apparent contradiction of two provisions of a directive on the qualification and training of drivers for certain vehicles; Q3/2019/MDC from the regional Ombudsman of Tuscany on whether allowing the modification of driver seats to allow for swivel car seats is left to the discretion of national authorities or not; Q5/2017/JN from Austria on the applicability of the GDPR on national ombud offices; Q3/2015/JAP from the Irish Ombudsman on the temporal scope of regulations in the field of agriculture; and Q1/2015/JAS from the Austrian Ombudsman Board as to whether an activity is covered by the VAT Directive.

${ }^{93}$ See Q1/2018/EIS.

${ }^{94} \mathrm{See}$ Q2/2015/DR.

${ }^{95}$ See Q1/2015/JAS.

${ }^{96}$ See Q1/2018/EIS.

${ }^{97}$ See Q2/2015/DR.

${ }^{98}$ See Q4/2020/MHZ. 
concerns of the Finnish Ombudsman about the compatibility of EU rules on rail passengers' rights with respect to the UN Convention on the Rights of Persons with Disabilities. ${ }^{99}$ In one case that concerned the administrative practice of FRONTEX, the Spanish Ombudsman noted that the EU agency should provide comprehensive information about the complaints mechanism ${ }^{100}$ on its website and provide the complaint forms in various languages. Following an exchange of views, and after the Spanish Ombudsman's dissatisfaction with the initial replies that were provided, FRONTEX eventually took some steps to accommodate these suggestions. ${ }^{101}$ In other instances, the Commission noted that the problem brought up by the national ombud offices was the object of ongoing working groups. ${ }^{102}$ However, there have also been instances where the Commission responded that it does not see any need to change its policy and that the existing rules are fit for its purpose. ${ }^{103}$

In instances where the query reveals indications that the Member State concerned might not have correctly transposed or implemented EU law, the Commission may choose to treat the information received as a so-called "infringement complaint" 104 after prior consultation with the referring national ombud office. More specifically, following a query from the Ombudsman of Malta concerning the transposition of relevant EU rules on road safety and access to environmental information into the national legal order, the Commission, in coordination with the national Ombudsman, treated the information as a complaint that could trigger the infringement procedure. ${ }^{105}$ However, the Commission does not seem to have an established approach that all queries revealing transposition or implementation problems would trigger an infringement investigation, even at a preliminary level. More specifically, in three instances, the Commission in its replies concluded that the Member State concerned had not acted in accordance with EU law. ${ }^{106}$ Nevertheless, it did not add in its replies that it would further investigate the case with the possibility to trigger an infringement procedure, or at least so it appears from the public summary available on the ENO website. According to the caselaw, the Commission enjoys a wide margin of appreciation when deciding whether to start an infringement procedure and therefore no failure to act may be established in this respect. ${ }^{107}$ Despite the absence of a legal obligation for the Commission to initiate an infringement procedure, when the Commission's reply suggests that the Member State concerned seems to violate EU law, the principle of good administration would

\footnotetext{
${ }^{99} \mathrm{See}$ Q8/2016/EIS.

${ }^{100}$ It should be noted that FRONTEX was initially very skeptical of establishing an internal complaints mechanism. The European Ombudsman investigated this matter, and this actually led to a special report in 2013 to the European Parliament, one of the limited number of cases where such a step was taken. See Decision of the European Ombudsman Closing OwnInitiative Inquiry OI/5/2012/BEH-MHZ Concerning the European Agency for the Management of Operational Cooperation at the External Borders of the Member States of the European Union (Frontex) (Nov. 12, 2013), https://europa.eu/!Yq89pM. More recently, in November 2020, a fresh own-initiative inquiry was launched against the complaint mechanism. See European Ombudsman, Case OI/5/2020/MHZ, How the European Border and Coast Guard Agency (Frontex) Deals with Complaints About Alleged Fundamental Rights Breaches Through its 'Complaints Mechanism', https://europa.eu/!kd46yt. ${ }^{101}$ See Q3/2017/MDC.

${ }^{102}$ See Q4/2017/EIS with reference to a working group of Eurostat and Q1/2017/JAP with reference to a Commission working group analyzing data and evidence collected by national consumer authorities.

${ }^{103}$ See Q6/2017/MDC; Q3/2016/JAP.

${ }^{104}$ See TFEU at art. 258. On the informal exchange procedure between the Commission and Member States, the so-called EU pilot, see Single Market Scoreboard, Eur. CoMm'N, https://ec.europa.eu/internal_market/scoreboard/performance_by_ governance_tool/eu_pilot/index_en.htm. See also Melanie Smith, The Evolution of the Infringement and Sanction Procedures: Of Pilots, Diversions, Collisions and Circling, in THE Oxford HANDBook of EU LAW 350-375 (Anthony Arnull \& Damian Chalmers eds., 2015).

${ }^{105}$ See Q6/2016/EIS.

${ }^{106}$ See Q1/2020/JAP; Q2/2018/EIS; Q4/2016/JN.

${ }^{107}$ See, among others, ECJ, Case C-412/18 P, Anthony Andrew King v. Eur. Comm'n, ECLI:EU:C:2018:947 (Nov. 22, 2018), http://curia.europa.eu/juris/liste.jsf?num=C-412/18; ECJ, Case C-137/16, Juozas Edvardas Petraitis v. Eur. Comm'n, ECLI: EU:C:2016:904 (Nov. 24, 2016), http://curia.europa.eu/juris/liste.jsf?num=C-137/16; ECJ, Case C-235/12 P, H-Holding AG v. Eur. Comm'n, ECLI:EU:C:2013:132 (Feb. 28, 2013), http://curia.europa.eu/juris/liste.jsf?num=C-235/12.
} 
require that the Commission at least explain what course of action it would undertake as guardian of the Treaties. ${ }^{108}$ In one case, the Commission concluded that it did not have enough information to assess whether the Member State concerned was violating EU law or not without asking for more information or redirecting the complaint. ${ }^{109}$ This case shows that better guidance to ombud offices as to which information they should add in their query could strengthen the effectiveness of the instrument. Lastly, in one case the Commission expressed clearly the opinion that in its view the Member State concerned was not infringing EU law. ${ }^{110}$ This matter is returned to below, where certain challenges from the EU query process are reflected upon.

Following the Commission's reply, national ombud offices have the possibility to ask for clarifications. Indeed, there have been instances where the national office reasserted the interpretation difficulties they had, which did not appear to be solved by the Commission's reply. For example, the Danish Ombudsman had asked whether Directive 2003/4/EC on Public Access to Environmental Information is to be interpreted so that information in a case about the renewal of a license to serve alcohol in a pub, including information on whether the conditions for granting the license were met and which information was considered important in that context, must be considered to be covered by the definition of environmental information as set out in the directive. ${ }^{111}$ The Commission replied that based on the caselaw, this is not covered by the notion of environmental information. The Danish Ombudsman was initially dissatisfied with the reply that had been provided and asked for further clarifications. The Commission clarified that the concept of environmental information according to the caselaw needs to have an actual or foreseeable-as determined under realistic conditions, and not theoretical-link with the environment.

Whenever a query appears to reveal an interpretational problem that might be faced by several ombud offices, the European Ombudsman may pose the question to the whole Network, so as to enquire for the potential existence of a systemic problem. For example, following a query from the Belgian Federal ombud offices on the application of the Citizens' Rights Directive (Directive 2004/ 38/EC) $)^{112}$ concerning problems with obtaining entry visas for non-EU family members of EU citizens, the European Ombudsman posed the query to the Network and in the end concluded that there was no systemic problem. ${ }^{113}$ In a different case, concerning the right to family benefits in cross-border situations, the Austrian Ombudsman Board reported that there were significant delays when two Member States had to decide which one should pay the family/child benefits and that the directive's provisions on provisional payment of benefits by the Member State of residence in case of disagreement became, in practice, dead letter. It also noted that SOLVIT, the informal platform for dispute solving among Member States, ${ }^{114}$ had not improved the situation. ${ }^{115}$ The Commission in its reply noted that the Directive offers clear solutions for the case of provisional benefits and that, to its knowledge, only Austria and the Czech Republic had faced problems. The Austrian office replied that it considered the problem systemic. Following activation of the

\footnotetext{
${ }^{108}$ On the Commission's role as guardian of the Treaties, see, in particular, Treaty on the European Union art. 17(1), Feb. 7, 1992, 1992 OJ (C 191) 1 [hereinafter TEU]; TFEU art. 258. On the Commission's obligation to explain its course of action following an infringement complaint, as deriving from the principle of good administration, see CAROL HARLOW \& RICHARD Rawlings, Process and Procedure in EU Administration 156 (2014).

${ }^{109}$ See Q7/2016/MDC.

${ }^{110}$ See Q9/2016/MDC.

${ }^{111}$ See Q3/2018/EIS.

${ }^{112}$ See Directive 2004/38/EC, of the European Parliament and of the Council of 29 April 2004 on the Right of Citizens of the Union and their Family Members to Move and Reside Freely Within the Territory of the Member States, art. 5, 2004 O.J. (L 158) 77.

${ }^{113}$ See Q4/2018/JAP.

${ }^{114}$ See Solvit: Solutions to Problems With Your EU Rights, EUR. COMM’N, https://ec.europa.eu/solvit/index.htm. For a review, see Michael Kaeding \& Friederike Voskamp, Better Implementation of EU Legislation is Not Just a Question of Taking Member States to Court (Eur. Inst. of Pub. Admin., Working Paper No. W/01/2011, 2011); Micaela Lottini, The SOLVIT Network: State of the Art and Possible Future Developments, 13 Rev. Eur. AdmIn. L. 109 (2020).

${ }^{115}$ See Q2/2018/EIS.
} 
Network, six ombud offices replied that they faced similar problems. The EU query process thus revealed that the application problem was wider than described by the Commission.

Overall, the examination of all queries published on the European Ombudsman's website since 2015 has demonstrated that the submitted questions from national ombud offices have covered a wide range of subject matters that transverse the whole spectrum of EU law. All questions had a legal interpretation angle but were often coupled with enquiries on future policy choices or requests for information. When the questions concerned legal interpretation, the Commission has made recourse either to existing caselaw or to interpretation guidance issued by itself or by joint working groups of the Commission and Member States. In the absence of those, the Commission reverted to the classic methods of legal interpretation, mainly responding on the basis of what could reasonably and logically be derived from the legal text or by referring to the literal meaning of terms. Regarding the questions on future policy, the Commission either made reference to existing provisions, replying that in its view the concerns of the national ombud offices are already adequately addressed, or, if it found that there was indeed a lacuna or an unregulated problem, committed to take it into account for future revision.

\section{To What Extent Do the EU Queries Resemble or Depart from the Preliminary Reference to the Court of Justice of the European Union?}

This section will offer a comparative examination of the EU queries system and the preliminary reference under article 267 TFEU and the caselaw arising thereof. It will draw on both the broader discussion on the establishment and framework of the EU queries discussed in Section B-as well as the analysis of the published queries that are available on the European Ombudsman's website from Section C. Overall, and despite some broader procedural similarities-namely that a question involving EU law is submitted from the domestic/regional level to the supranational levelthis Article argues that the EU queries system performs an entirely different function. Therefore, it would probably be misleading to view this as a form of extra-judicial preliminary reference in the field of maladministration. It is instead an informal way for national ombud offices to obtain interpretation guidance, in a non-authoritative way, from EU institutions, and in particular the Commission, through the coordination of the European Ombudsman.

Before this, a few broader remarks about the preliminary reference are apposite. The preliminary reference has been described by the CJEU itself as "an instrument of cooperation" between that court and national courts ${ }^{116}$ on matters of interpretation of EU law. Of course, Article 19(1) TEU states that the CJEU "shall ensure that in the interpretation and application of the Treaties the law is observed." Whether the reality, especially after Köbler, ${ }^{117}$ corresponds to a system of a "cautious," "vertical" relationship is a matter of debate. ${ }^{118}$ And beyond the relations with national

\footnotetext{
${ }^{116}$ See, among others, ECJ, Case C-361/97, Rouhollah Nour v. Burgenländische Gebietskrankenkasse, ECLI:EU:C:1998:250 (May 25, 1998), para. 10, http://curia.europa.eu/juris/liste.jsf?num=C-361/97; ECJ, Case C-380/01, Gustav Schneider v. Bundesminister für Justiz, ECLI:EU:C:2004:73 (Feb. 5, 2004), para. 20, http://curia.europa.eu/juris/liste.jsf?num=C-380/01; ECJ, Case C-445/06, Danske Slagterier v. Bundesrepublik Deutschland, ECLI:EU:C:2009:178 (Mar. 24, 2009), para. 65, http://curia.europa.eu/juris/liste.jsf?num $=\mathrm{C}-445 / 06$. The CJEU has also referred to the preliminary reference as the "keystone" of the EU judicial system. See ECJ, Case Opinion 2/13, ECLI:EU:C:2014:2454 (Dec. 18, 2014), paras. 176, 198, http://curia.europa.eu/juris/liste.jsf?num $=\mathrm{C}-2 / 13$.

${ }^{117}$ See ECJ, Case C-224/01, Gerhard Köbler v. Republik Österreich, ECLI:EU:C:2003:513 (Sept. 30, 2003), http://curia. europa.eu/juris/liste.jsf?num=C-224/01 (confirming the possibility of Member State liability for breaches of EU law committed by national courts adjudicating at last instance). That judgment should now be read, perhaps, alongside Eur. Comm' $n$, Case C-416/17 in that it stresses the importance for national courts of last resort to engage with the CJEU.

${ }^{118}$ Thomas de la Mare \& Catherine Donnelly, Preliminary Rulings and EU Integration: Evolution and Stasis, in THE Evolution of EU Law 363, 376-78 (Paul Craig \& Gráinne de Búrca eds., 2011). As the authors explain, it is probably unrealistic to describe the preliminary reference "as based solely on cooperation" as it has developed—albeit cautiously—into a coordination scheme with the CJEU "at the apex of the hierarchy." See also Jan Komárek, Federal Elements in the Community Judicial System: Building Coherence in the Community Legal Order, 42 COMMON MKT. L. REV. 9 (2005).
} 
courts, insights on how the CJEU views the preliminary reference could also be drawn from its widely discussed-and criticized-Opinion on the EU accession to the ECHR, where it was highlighted that the characteristics of the preliminary reference procedure should not be undermined by the EU's accession to the ECHR. ${ }^{119}$ Studies have shown how domestic courts of last resort use, or refrain from using, the preliminary reference procedure, ${ }^{120}$ which also provides insights on whether the domestic view subscribes to a model of hierarchy or equal cooperation. This question will undeniably receive further scholarly attention after the recent and already widely criticized German Federal Constitutional Court's judgment ${ }^{121}$ on the European Central Bank's Public Sector Purchase Programme (PSPP). ${ }^{122}$ It might also be added that, outside the EU but within the Council of Europe, the entry into force of Protocol 16 ECHR, with respect to the contracting parties that have ratified it, has already led the European Court of Human Rights to deliver two advisory opinions. ${ }^{123}$

Let us now turn to the comparison between the EU query and the preliminary reference. To begin with, the EU query is in principle answered either directly by the European Ombudsman or, in the vast majority of cases, by the best placed EU authority, which is almost exclusively the Commission. The preliminary reference is, of course, answered by the Court of Justice. ${ }^{124}$ As to who can submit a query or a reference, in the former case the answer would point to the ENO membership, which means that, in principle, this membership at a certain point in time appears to be closed, but also includes offices outside the EU. In the latter case, the possibility to refer is reserved to "courts" or "tribunals," as interpreted by the caselaw of the CJEU, ${ }^{125}$ which

\footnotetext{
${ }^{119}$ Case Opinion $2 / 13$ at paras. $196-200$.

${ }^{120}$ See Monica Claes, Luxembourg, Here We Come? Constitutional Courts and the Preliminary Reference Procedure, 16 GERMAN L.J. 1331 (2015), as well as further contributions in that special issue; Anthony Arnull, The Use and Abuse of Article 177 EEC, 52 Mod. L. Rev. 622 (1989); Anthony Arnull, The UK Supreme Court and References to the CJEU, 36 Y.B. EUR. L. 314 (2017).

${ }^{121}$ Bundesverfassungsgericht [BVerfG] [Federal Constitutional Court], 2 BvR 859/15, May 5, 2020, http://www.bverfg.de/e/ rs20200505_2bvr085915en.html.

${ }^{122}$ Which also produced an unusual press release from the Court of Justice, reiterating its case law that a preliminary ruling is binding on the national court. See ECJ, Case C-446/98, Fazenda Pública v. Câmara Municipal do Porto, ECLI:EU:C:2000:691 (Dec. 14, 2000), para. 49, http://curia.europa.eu/juris/liste.jsf?num=C-446/98. Only the Court of Justice can declare an EU act invalid. See, e.g., Foto-Frost, Case 314/85 at paras. 15-17. National courts should ensure that provisions of EU law take full effect. See ECJ, Case C-212/04, Konstantinos Adeneler and Others v. Ellinikos Organismos Galaktos (ELOG), ECLI:EU: C:2006:443 (July 4, 2006), para. 122, http://curia.europa.eu/juris/liste.jsf?num=C-212/04. See also Court of Justice of the European Union Press Release 58/20, Press Release Following the Judgment of the German Constitutional Court of 5 May 2020 (May 8, 2020), https://curia.europa.eu/jcms/upload/docs/application/pdf/2020-05/cp200058en.pdf.

${ }^{123}$ See Eur. Ct. H.R., Advisory Opinion Concerning the Use of the "Blanket Reference" or "Legislation by Reference" Technique in the Definition of an Offence and the Standards of Comparison Between the Criminal Law in Force at the Time of the Commission of the Offence and the Amended Criminal Law (May 29, 2020), https://www.echr.am/resources/ echr//judgments/19963d5f567f262c689eab822767f39c.pdf; Eur. Ct. H.R., Advisory Opinion Concerning the Recognition in Domestic Law of a Legal Parent-Child Relationship Between a Child Born Through a Gestational Surrogacy Arrangement Abroad and the Intended Mother (Apr. 10, 2019), http://hudoc.echr.coe.int/spa?i=003-6380464-8364383.

${ }^{124}$ Note that, in principle, the General Court could also be involved in the preliminary reference. See TFEU art. 256(3). This faculty has not, to date, materialized.

${ }^{125}$ The caselaw of the CJEU takes into account a number of factors to answer this question, such as "whether the body is established by law, whether it is permanent, whether its jurisdiction is compulsory, whether its procedure is inter partes, whether it applies rules of law and whether it is independent." See Joined Cases C-110 \& 147/98, Gabalfrisa SL and Others v. Agencia Estatal de Administración Tributaria (AEAT), ECLI:EU:C:2000:145, para 33, Judgment of 21 March 2000; ECJ, Case C-407/98, Katarina Abrahamsson and Leif Anderson v. Elisabet Fogelqvist, ECLI:EU:C:2000:367 (July 6, 2000), para. 29, http://curia.europa.eu/juris/liste.jsf?num=C-407/98; ECJ, Case C-53/03, Synetairismos Farmakopoion Aitolias \& Akarnanias (Syfait) and Others v. GlaxoSmithKline plc and GlaxoSmithKline AEVE, ECLI:EU:C:2005:333 (May 31, 2005), paras. 29-38, http://curia.europa.eu/juris/liste.jsf?num=C-53/03 (finding that Epitropi Antagonismou, the Greek competition authority, does not meet these requirements). Bodies which merely perform administrative, non-judicial functions in the given case cannot submit a preliminary reference. See, e.g., ECJ, Case C-111/94, Job Centre Coop. ARL, ECLI:EU:C:1995:340 (Oct. 19, 1995), para. 11, http:// curia.europa.eu/juris/liste.jsf?num=C-111/94; ECJ, Case C-394/11, Valeri Hariev Belov v. CHEZ Elektro Balgaria AD and Others, ECLI:EU:C:2013:48 (Jan. 31, 2013), para. 51, http://curia.europa.eu/juris/liste.jsf?num=C-394/11. Not everyone agrees that the above criteria are exceptionally clear. See, e.g., Opinion of Advocate General Colomer at para. 14, Case C-17/00, François De Coster v. Collège
} 
means that the possible candidates for submission are substantially broader, yet confined within the EU. ${ }^{126}$

Nevertheless, in the ENO case, the informality of the network and the existing arrangements would not render the submission-for example - of a query from a national human rights office that is not part of the ENO an impossible scenario. Alternatively, it should be possible for a national human rights office or another body that is not an ENO member to transfer the query to the ENO member, the latter then contacting the European Ombudsman via the usual query process. An office within the national ombud office can also submit a query, as has been the case with the Maltese Commissioner for Environment and Planning, ${ }^{127}$ who is part of the office of the Parliamentary Ombudsman. ${ }^{128}$

In addition, the EU query process, much like the ENO more generally, ${ }^{129}$ is based on voluntary participation and cooperation. Thus, the national office is not obliged to refer to the European Ombudsman, while under Article 267 TFEU and the caselaw of the CJEU, ${ }^{130}$ the national courts, under certain circumstances, are obliged to refer. Whether they always comply with such an obligation is, of course, an entirely different matter. ${ }^{131}$ Not complying with this obligation might even trigger an infringement procedure, ${ }^{132}$ and might also constitute a violation of Article 6(1) ECHR, ${ }^{133}$ whereas not submitting a query has no legal consequences and an ombud office cannot be forced to do so.

National offices cannot, of course, challenge the validity of an EU act via the EU queries procedure. Leaving aside the views of the German Federal Constitutional Court, it might be worth recalling that only the Court of Justice has jurisdiction to invalidate an EU act. ${ }^{134}$ However, nothing prevents an ombud office to make a query expressing its concerns about the conformity of an EU rule with higher norms or with international obligations of the EU and seek the Commission's opinion on this, as noted above. ${ }^{135}$ The Commission indeed replied to the concerns of the Finnish Parliamentary Ombudsman on the compatibility of EU rules with the UN Convention of the Rights of Persons with Disabilities by committing to take them into account in the ongoing revision of the relevant legislation. ${ }^{136}$

As to the interpretation of EU law, it is well known that preliminary references are binding on the domestic courts for the purpose of the decision in the main proceedings. ${ }^{137}$ It is then left to the

des bourgmestre et échevins de Watermael-Boitsfort (Nov. 29, 2001). For further discussion, see BROBERG \& FENGER, supra note 1, at 60-106.

${ }^{126}$ The Court has held that it has jurisdiction to give preliminary rulings further to requests received only by courts or tribunals of Member States. See, e.g., ECJ, Case C-321/97, Ulla-Brith Andersson and Susannne Wåkerås-Andersson v. Svenska Staten (Swedish State), ECLI:EU:C:1999:307 (June 15, 1999), http://curia.europa.eu/juris/liste.jsf?num=C-321/97.

${ }^{127}$ See Q7/2016/MDC.

${ }^{128}$ See Eur. OMbudsman, supra note 40.

${ }^{129}$ See also, on this point, Carol Harlow \& Richard Rawlings, Promoting Accountability in Multilevel Governance: A Network Approach, 13 Eur. L.J. 542, 559 (2007).

${ }^{130}$ See supra notes $2 \& 3$.

${ }^{131}$ See references supra note 120 , which are not exhaustive of this topic, of course. In his famous Opinion in UPA, Advocate General Jacobs also pointed out that national courts may not always refer, this being one of the reasons why a new approach to standing was proposed. Opinion of Advocate General Jacobs at para. 42, Case C-50/00 P, Unión de Pequeños Agricultores v. Council of the European Union (Mar. 21, 2002).

${ }^{132}$ See Eur. Comm'n, Case C-416/17.

${ }^{133}$ See, among others, Dhahbi v. Italy, App. No. 17120/09, paras. 31-34 (Apr. 8, 2014), http://hudoc.echr.coe.int/eng?i=001142504

${ }^{134}$ See Foto-Frost, Case $314 / 85$ at paras. $15-17$.

${ }^{135}$ See Q8/2016/EIS. This query is referred to in Section C.

${ }^{136}$ See id.

${ }^{137}$ See ECJ, Case C-52/76, Luigi Benedetti v. Munari F.lli s.a.s., ECLI:EU:C:1977:16 (Feb. 3, 1977), para. 26, http://curia. europa.eu/juris/liste.jsf?num=C-52/76. 
national court to apply the interpreted rules in the dispute at hand. ${ }^{138}$ The reason that such interpretation is binding is similar to the logic behind the sole authority of the Court of Justice to invalidate an EU act; the uniform application and interpretation of EU law should be preserved. The outcome of the query process does not represent an authoritative interpretation of EU law, and it is not binding on the national office or other similar offices across the EU. As noted above, the Commission often includes an explicit disclaimer in its replies that only the Court may deliver a binding interpretation of EU law. ${ }^{139}$ However, the Commission, through its replies, expresses its view on how EU law should be applied in its capacity as guardian of the Treaties; a view that it is likely to follow in case an infringement procedure or a court case would arise on the specific subject matter. Therefore, it should be underlined that this interpretation guidance provided by the Commission has a value of its own, even if it is not of an authoritative nature. For instance, if the Commission expresses concerns about the conformity with EU law of a Member State's legislation or application practice in its reply to a query, it is likely that it will express the same view in the future, should an infringement procedure be initiated or should the same question be brought before the CJEU on the basis of an infringement procedure.

When the guidance of the query process coincides with the interpretation of the Court of Justice, no issues could arise. By contrast, it would be highly problematic if the European Ombudsman or the Commission would provide an interpretation of EU law that would conflict with that of the Court of Justice. Among the cases examined under Section C, no such example was found. However, while this challenge should be recognized, this cannot lead us to question the usefulness of the EU query process. On the one hand, EU law is interpreted and applied across Member States on a daily basis by courts, administrations, ombud offices, and other institutions. It is impossible for the Court - or the Commission, which is the "guardian of the treaties" - to identify all instances of misapplication or misinterpretation of EU law. And clearly not all courts, when in doubt, refer to the Court of Justice, even when they have an obligation-at least according to the case law of the CJEU - to do so. On the other hand, the European Ombudsman, who oversees the EU queries process and can be deemed to take responsibility for the operation of the scheme, has never claimed that she or he provides an authoritative interpretation of EU law. By contrast, the European Ombudsman and the Commission have emphasized that the highest authority on the interpretation of EU law is the CJEU. ${ }^{140}$ What the European Ombudsman has not refrained from doing, however, is to actually interpret EU law, even in situations where the legal issue had not been settled by the Court of Justice. Incidentally, this approach, especially in the first years of the European Ombudsman's operation, was not met with enthusiasm - to put it mildly-by the Commission, as the Ombudsman was keen to investigate, in particular, complaints concerning its role as the guardian of the treaties. ${ }^{141}$ In any case, the EU query process aims to assist the national offices rather than to authoritatively interpret the law. And it is needless to say that the Commission closely monitors the jurisprudence of the Court of Justice in all fields of EU law, while the European Ombudsman does not dispose of such expertise in all fields. ${ }^{142}$

The informality of the EU query process also entails that there are no rigid rules as to how the question should be formulated. From the queries examined under Section C, at least from the published summaries, it can be concluded that the exact facts of the case, as well as the content of the national provisions at stake, are not always analyzed. Furthermore, the necessity of the answer to the query in order to solve a specific case that arose before the national ombud office is not always explicitly mentioned or justified. This is in stark contrast to the preliminary

\footnotetext{
${ }^{138}$ ECJ, Joined Cases C-28 \& 30/62, Da Costa en Schaake NV et al. v. Netherlands Inland Revenue Admin., ECLI:EU: C:1963:6, Judgment of 27 Mar. 1963.

${ }^{139}$ See Q1/2020/JAP; Q3/2015/JAP. These were referred to in Section C.

${ }^{140}$ See, among many examples, EOAR 2008 at 57 and queries Q1/2020/JAP and Q3/2015/JAP.

${ }^{141}$ See Nikos Vogiatzis, Communicating the European Ombudsman's Mandate: An Overview of the Annual Reports, $10 \mathrm{~J}$. CONTEMP. EUR. RES. 105, 114 (2014).

${ }^{142}$ The European Ombudsman will frequently do so in the closing statement of a query published on the ENO's website.
} 
reference, whereby the Court of Justice has established clear rules on the information that is required, ${ }^{143}$ and has also addressed recommendations - with further guidance- to national courts. ${ }^{144}$ Moreover, the question as to whether the query that is referred to should necessarily be of a legal nature can be posed. As it became clear from the analysis of the published EU queries referred to in Section C, the legal questions concerning the interpretation of EU law are in most cases coupled with requests for information or enquiries about future policy changes. Yet, in all the queries examined under Section $\mathrm{C}$, there has always been a legal interpretation angle.

It should also be noted that queries on EU-related matters need not necessarily concern the handling of a specific case or complaint, while in the case of the preliminary reference, time and again the CJEU has clarified that "the justification for a reference for a preliminary ruling is not that it enables advisory opinions on general or hypothetical questions to be delivered but rather that it is necessary for the effective resolution of a dispute." ${ }^{145}$ The actual advantage of this flexibility is that a question may be posed even before a case escalates and ends up at the Court, while a preliminary reference procedure requires that a case is pending before a national court.

Furthermore, the national court that receives the interpretation guidance from the CJEU has in principle the possibility to refer back to the court and engage in a dialogue with it. ${ }^{146}$ However, such an exchange will last several years, with obvious implications for the length of domestic proceedings, whereas the real advantage of the EU queries procedure is that the ombud offices may ask for clarifications and receive an immediate follow-up reply within a few weeks or even days. This possibility has indeed been used, as already noted.

\section{E. What Are the Challenges Regarding the EU Queries Process, and How Could These be Addressed?}

The distinctiveness of the EU query process as illustrated in the previous section indicates its value as a more flexible and informal mechanism that assists the national office. This does not necessarily entail, however, that challenges cannot be identified, and suggestions for improvement be proposed.

Before proceeding further, it should be clarified that the question as to whether a national ombud office should be able to submit a preliminary reference to the CJEU is not examined here. ${ }^{147}$ The current position is that such offices normally would not qualify under Article 267 TFEU, as they would not meet the requirements as set out by the caselaw of the Court on the definition of "courts or tribunals." ${ }^{48}$ If anything, this serves as further evidence of the value of the EU query procedure for ombud offices.

\footnotetext{
${ }^{143}$ See Court of Justice of the European Union, Consolidated Version of the Rules of Procedure of the Court of Justice, Title III (Sep. 25, 2012) curia.europa.eu/jcms/upload/docs/application/pdf/2012-10/rp_en.pdf.

${ }^{144}$ Court of Justice of the European Union, Recommendations to National Courts and Tribunals in Relation to the Initiation of Preliminary Ruling Proceedings, 2019 O.J. (C 380) 1.

${ }^{145}$ See, more recently, ECJ, Case C-621/18, Andy Wightman and Others v. Sec'y of State for Exiting the E.U., ECLI:EU: C:2018:999 (Dec. 10, 2018), para. 28, http://curia.europa.eu/juris/liste.jsf?num=C-621/18 and case law cited therein. How faithfully the CJEU has followed this position is, of course, subject to academic debate. For a useful discussion, see, for example, Broberg \& FENGER, supra note 1, at ch. 5.

${ }^{146}$ As an example of a rare dialogue between the CJEU and national courts, see the Taricco case with a follow-up preliminary reference from the Italian Constitutional Court. See ECJ, Case C-105/14, Crim. Proc. Against Ivo Taricco and Others, ECLI: EU:C:2015:555 (Sep. 8, 2015), http://curia.europa.eu/juris/liste.jsf?num=C-105/14; ECJ, Case C-42/17, Crim. Proc. Against M.A.S. and M.B., ECLI:EU:C:2017:936 (Dec. 5, 2017), http://curia.europa.eu/juris/liste.jsf?num=C-42/17. See also Cass., Order No. 24/2017 (It.), https://www.cortecostituzionale.it/documenti/download/doc/recent_judgments/O_24_2017.pdf. This dialogue lasted, however, several years.

${ }^{147}$ See Morten P. Broberg, Preliminary References by Public Administrative Bodies: When are Public Administrative Bodies Competent to Make Preliminary References to the European Court of Justice?, 15 Eur. PUB. L. 207, 220-21 (2009).

${ }^{148}$ See citations supra note 125.
} 
This brings us to the challenges of the EU queries as a non-judicial process. Initially, some of these challenges emerge from the diverse content of the queries analyzed in this Article, which range from questions pertaining to interpretational difficulties that national ombud offices face when applying EU law to queries challenging the compatibility of national norms with EU law to requests directed to the EU institutions to revise policy choices. The key challenge that arises from this diverse use is how to reserve a distinctive character for this tool while clearly delineating it from other instruments, notably the infringement procedure, and preserving a sufficient degree of informality when compared with the preliminary reference. Put differently, and considering the position of national ombud offices, a question worth reflecting upon is when they should use the EU queries procedure in the place of other instruments. To that end, despite the clear link between the two notions, flexibility is not synonymous with informality. In that sense, this Article may be viewed as claiming that the existing flexibility should be maintained while the degree of informality should be reduced.

In this respect, it is recalled that, although the query procedure has a history that almost follows the establishment of the office of the European Ombudsman, the relatively low number of yearly queries, the absence of certain big Member States among the ombud offices that have made use of this process, and the lack of periodicity by those Member States making use of it probably indicate the absence of an established and distinctive character for this scheme. This is in stark contrast not only with its potential, but also with the actual contribution to the implementation and application of EU law that the scheme has provided. ${ }^{149}$ Such important contribution therefore appears to have taken place on an ad hoc basis, rather than on the basis of a developed and fully operational institutional framework or practice.

When a national ombud office faces an interpretational difficulty, recourse to the query process seems like a valuable possibility to obtain useful and generally speedy guidance from the EU institutions, not least because, as explained above, a preliminary reference coming from an ombud office would probably be inadmissible. Therefore, in such cases, the query procedure, even if the interpretation guidance that it offers may not be authoritative and may be overturned in a future case by the CJEU, might still constitute the only guidance an ombud office is able to receive.

In cases where national ombud offices are concerned about the compatibility of national norms with EU law, the question arises whether they should use the query procedure to express such concerns or whether they should instead seize the Commission directly with a view to triggering an infringement procedure. The latter seems more suitable if the national ombud office has serious concerns on the possible violation of EU law by the Member State concerned, because the EU query process has on its own no legal effects and thus could not force a Member State to engage in remedial action. However, given the wide discretion that the Commission enjoys when deciding to trigger the infringement procedure, the query process, especially when it reveals a structural problem that might be shared across the ENO membership or part thereof, may render an EU law violation more visible and thus exercise political pressure on the Commission.

Regarding the instances when national ombud offices use the query procedure in order to try to influence the Commission on future policy choices and eventual revision of existing legal rules, the comparison with another legal tool is not evident. This is yet another useful contribution of the EU query process, which is again associated with its informal nature. The European Commission organizes, of course, public consultations ${ }^{150}$ and sets up expert groups in order to better inform its policies. However, the Commission determines the timing of such input-giving processes. The unique advantage of the EU query is that it gives the opportunity to every ombud office to effectively inform the Commission at any time on a policy gap or revision need and engage in a dialogue with it. In certain replies to EU queries, the Commission has noted that it will take the query

\footnotetext{
${ }^{149}$ See supra earlier sections and especially Section C.

${ }^{150}$ See TEU art. 11(3). See also Consultations, EUR. COMM'N, ec.europa.eu/info/about-european-commission/service-standards-and-principles/transparency/consultations_en.
} 
into account when revising the relevant legislative document. It will be interesting to observe whether in future proposals the Commission will refer to the EU queries as a justification for certain amendments or policy choices alongside other sources, such as impact assessments, public consultations, et cetera.

Having established that the main added value of the EU query process is to fill the lines and gaps between other, more established and formal instruments, a challenge remains under the present arrangements: How to preserve the flexible nature of the query process while increasing its transparency, visibility, and control by other stakeholders and institutions who have an interest in the interpretation guidance given. Of relevance here are the earlier remarks that normally only a summary of the query is provided, ${ }^{151}$ the use of the interpretative guidance by the national office at times remains unclear, and there is a lack of information on the follow-up after the submission of the reply.

Given the impact that a reply to an EU query may have on the application of EU law, a more formalized approach could enhance the transparency and overall visibility of this important cooperation tool, as well as secure the interests of all the parties and institutions involved. This more formalized approach could start by providing guidance to national ombud offices as to the exact elements that they should include in their queries. There is no doubt that the existing guidance by the CJEU to national courts when submitting a preliminary reference has facilitated the good functioning of their collaboration. ${ }^{152}$ The provision of such guidance to national ombud offices would also enhance the usefulness of the process because, in certain instances, the Commission responded that it lacks all necessary information to respond to the query. ${ }^{153}$ It should be emphasized, however, that the guidance referred to above should not be binding or rigid; for example, leading to the inadmissibility of the submitted query. In this way, the informality of the process, as well as its distinctiveness from the preliminary reference, are preserved. Furthermore, for reasons of transparency and also for more visibility and better use by other institutions and stakeholders involved in the application of EU law, the European Ombudsman should set out the exact elements of the query process and the replies given to the national ombud offices that should be published online in the anonymized summary. Relatedly, it is quite remarkable that the present ENO Newsletter, now titled "Network in Focus" and published annually, does not contain any references to the EU query process. ${ }^{154}$

Assuming that the EU query, informal as it is, has an educational value as well, it is also worth reflecting upon whether the ENO website should be enriched with further information about the follow-up to the query. The publication of follow-up studies is not unknown to the European Ombudsman, although admittedly and understandably, such studies focus primarily on compliance with the European Ombudsman's recommendations. ${ }^{155}$ Clearly, the jurisdictional limitations of the EU office would not enable a publication of this sort. However, it would certainly be useful to include further information on how the guidance has been used and whether challenges in the implementation of EU law persist.

In addition, it could further contribute to the effectiveness of the process if guidance from the EU office explained what other processes could be triggered after the revelation of certain facts via

\footnotetext{
${ }^{151}$ It is recalled that other ombud offices have access to the full query via the ENONET.

${ }^{152}$ See Court of Justice of the European Union, Recommendations to National Courts and Tribunals in Relation to the Initiation of Preliminary Rulings Proceedings, 2018/C 257/01 (July 20, 2018), https://eur-lex.europa.eu/legal-content/EN/ TXT/PDF/?uri=OJ:C:2018:257:FULL\&from=EN.

${ }^{153}$ See Q7/2016/MDC.

${ }^{154}$ This document has been published since 2016. There is one reference in the 2017 publication on page 17 to family reunification-discussed above supra note 76-and the possibility to use the queries procedure, but this was done to summarize the discussion, rather than present it in a systematic way. The newsletters are available at: www.ombudsman.europa.eu/ en/publications.

${ }^{155}$ See, in particular, the Putting it Right? reports by the European Ombudsman. The latest report is available at: www. ombudsman.europa.eu/en/annual/en/123473.
} 
the query procedure. More specifically, it would be essential to clarify under which circumstances the facts of an EU query should be treated by the Commission as an infringement, complaint, or, if the query process reveals maladministration by the EU institutions, an investigation by the European Ombudsman.

Regarding the infringement procedure in particular, national offices have expressed concerns about the compatibility of national law with EU law. Elsewhere, they have used the process to make the Commission aware of a problem and enquired how the Commission intends to act. The Commission appears to take a clear stance on whether or not the Member State concerned violates EU law, but it is unclear how the case is really followed up by the Commission, in essence, whether it uses this evidence to start the preliminary investigative phase of an infringement procedure. It is interesting to note that in its annual report on the application of EU law, ${ }^{156}$ the Commission does not mention the exchange through the EU queries. It was mentioned earlier that the Commission enjoys wide discretion in this area. This does not mean that the Commission's use of such discretion has not been criticized in the literature, ${ }^{157}$ or by the EU institutions, including the European Parliament, ${ }^{158}$ or indeed by the European Ombudsman herself. ${ }^{159}$ Equally, the Commission has not always been consistent in its practice. ${ }^{160}$ Yet, this is not the place to revisit such discussion. Instead, it will be asked whether additional mechanisms exist within the informal ENO architecture that may address the Commission's possible unwillingness to pursue further an infringement of EU law that has been unraveled via the query process.

To that end, the possibility for the European Ombudsman to launch a "parallel inquiry"161 constitutes a tool that can be used by the Ombudsman to apply additional pressure on the Commission to act. The aforementioned query on the Family Reunification Directive ${ }^{162}$ essentially presents the inverse scenario, but also shows how informal mechanisms within the ENO can interact. In that case, a shared concern among ENO members that was expressed at a conference led to the submission of a query by the Belgian Federal Ombudsman on a possible more favorable interpretation of the Directive. Because the European Ombudsman is always made aware of the reply to the Commission, nothing precludes a survey of ENO members on the extent of the problem that has been identified in a specific situation, and the launch of a "parallel inquiry" afterwards. In any case, the European Ombudsman is not prevented at any time from launching an inquiry against the Commission in its role as the "guardian of the Treaties," with or without any prior complaint. ${ }^{163}$

Lastly, the divergences of use of the query process across Member States, as well as the lack of periodicity in those states which have actually used the process, reveals another possible challenge of the scheme: That it very much depends on the intentions of the holders of the national offices. To be sure, ombud offices are largely more "personal" than courts, and this is an advantage of the

\footnotetext{
${ }^{156}$ The annual reports on monitoring the application of EU law can be found at https:/ec.europa.eu/info/publications/ annual-reports-monitoring-application-eu-law_en.

${ }^{157}$ See Melanie Smith, Enforcement, Monitoring, Verification, Outsourcing: The Decline and Decline of the Infringement Process, 33 Eur. L. REv. 777 (2008).

${ }^{158}$ See, in particular, Resolution of 6 October 2016 on Monitoring the Application of Union Law: 2014 Annual Report, EUR. PARL. Doc. 2015/2326(INI) (2016), point 16 (expressing concerns about the transparency of the EU pilot procedure).

${ }^{159}$ See VogiatzIs, supra note 9 , at $96-106$.

${ }^{160}$ As Smith observes, for example, in 2017 the Commission announced that the EU pilot would no longer be used for all infringement investigations. See Melanie Smith, Challenges in the Implementation of EU Law at National Level, EUR. PARL. Doc. PE 608.841, at 5 (2018), https://www.europarl.europa.eu/RegData/etudes/BRIE/2018/608841/IPOL_BRI(2018)608841_ EN.pdf; Commission Communication No. 2017/C 18/02, EU Law: Better Results Through Better Application, 2017 O.J. (C 18) 10, https://eur-lex.europa.eu/legal-content/EN/TXT/PDF/?uri=CELEX:52017XC0119(01)\&from=EN.

${ }^{161}$ See discussion supra notes $51-53$.

${ }^{162}$ See Q6/2017/MDC. This query is discussed in Section C.

${ }^{163}$ It is needless to say that a complaint to the European Ombudsman, in accordance with the provisions of the Treaty, the Ombudsman's Statute, and the Implementing Provisions is of course different to an EU query. Yet, the European Ombudsman can always launch an own-initiative or systemic inquiry, without the prior submission of a complaint.
} 
extra-judicial avenue. ${ }^{164}$ An office holder can shape the direction of the institution in a much more visible way than, for example, a president of a court. Simultaneously, more limited or no use of the EU queries may prevent instances of uncertainties around the interpretation or application of EU law to be brought to the fore. In light of this, a more formalized approach to the EU queries scheme could guarantee more consistency and could, perhaps, establish a solid culture of extra-judicial referrals, while respecting the flexible characteristics of the scheme.

\section{F. Concluding Remarks}

It is well known that national authorities are the key bodies that implement EU law. And while judicial cooperation might take several forms, some of which are formalized in EU treaties and elsewhere, the forms of extra-judicial cooperation remain underexplored in the literature. Starting from the position that there is a clear division of labor between the EU and national offices in the field of maladministration - a notion which, as noted above, might mean different things to different people but generally seeks to describe the contribution of ombud offices to accountabilitythis Article represents the first comprehensive study of the EU query process.

It was explained that the process is essentially a means for national offices to seek and receive non-authoritative interpretative guidance in a flexible and informal way. That this guidance is non-authoritative, as opposed to that provided the CJEU, should not detract from its value. Section C, in particular, has shown that the Commission's replies are based on firm legal grounds, taking also into consideration the caselaw of the Court but also other instruments, including soft law. The Commission's interpretative replies are also of particular significance because they demonstrate the Commission's views on, for example, the interpretation of a Directive. This is the view that the Commission is likely to follow in eventual infringement proceedings-in light of its role as guardian of the Treaties - or in its interventions before the Court in case of a preliminary reference procedure.

Thus, the query may also work as a way to inform the Commission in a structured way on interpretation or application difficulties that national authorities may encounter. This could be an additional source of useful information for the Commission in its monitoring of application of EU law and in its efforts to cooperate with national authorities in order to ensure correct and uniform application of EU law.

In this context, the advantages and its complementary function vis-à-vis the preliminary reference should not be underestimated. The words "informal" and, in particular, "flexible," perhaps encapsulate most of these advantages, which include the following: The question may be posed even before a case escalates and ends up in Court, while a preliminary reference procedure requires that a case is pending before a national court; the possibility to ask for clarifications when the national office is not satisfied with the Commission's reply or when the latter is not sufficiently clear, which facilitates a direct dialogue between institutions; the faculty to pose the question directly to the body that applies the relevant provision, to enquire about its practice and try to influence it, referring not only to the Commission but also other EU bodies or agencies, for example, FRONTEX; the queries can be used not only as a means of asking legal questions but also to enquire about future policy choices; and, in principle, it should be a faster than the judicial avenue to obtain an answer, in accordance with the European Ombudsman's policy, ideally within twenty working days, unless the Commission requires more time. Overall, the EU query process has a broader scope and more functions than the preliminary reference; its flexible design and process have contributed to this.

Moving on to the challenges of the existing arrangements, three can be revisited here. First, it is submitted that, given the impact that a reply to an EU query may have on the application of EU

\footnotetext{
${ }^{164}$ For the European Ombudsman, and the "personal dimension" to the office that has been adopted, this claim was made in Carol Harlow \& Richard Rawlings, Law ANd Administration 529 (2009).
} 
law, a more formalized approach could enhance the transparency and overall visibility of this important cooperation tool, as well as secure the interests of all the parties and institutions involved. It should be specified which elements should be published in the anonymized summary on the website; this is essential not only for reasons of transparency, but also for better use of the interpretation guidance provided by the Commission. Second, it may be the case that the query process reveals a broader and systemic problem across several Member States. When this is notified to the Commission, which, as is known, enjoys broad discretion in the context of the infringement process, a possible unwillingness on its part to pursue matters further should lead the European Ombudsman to exhaust the avenues within the ENO to exercise pressure on the Commission. If so, launching a "parallel inquiry" appears a plausible way to proceed. Third, and pointing again to the informality of the process, the varied used of the mechanism across Member States or the varied density of use within Member States that have engaged with the scheme bring to the fore not only the different modi operandi of national offices, or even their different understanding of the boundaries of maladministration, but also how much ombud offices can rely, at times, on the personal agenda of the office holder. If so, and quite inevitably, perhaps, the query process offers an incomplete picture of the implementation of EU law across Member States. It is hoped that this challenge can be addressed via the call for a measured formalization of the process that is advanced in this Article.

Cite this article: Athanasiadou N, Vogiatzis N (2021). The EU Queries: A Form of Extra-Judicial Preliminary Reference in the Field of Maladministration?. German Law Journal 22, 441-465. https://doi.org/10.1017/glj.2021.17 